\title{
Effect of Disinfectants on Bacterial Quorum Sensing in Drinking-Water Distribution System
}

\author{
Qipei Jiang \\ Institute of Environmental Protection of Baoding, Baoding, China \\ Email: cellulose420@163.com
}

Received 5 November 2015; accepted 19 November 2015; published 24 November 2015

Copyright (C) 2015 by author and OALib.

This work is licensed under the Creative Commons Attribution International License (CC BY).

http://creativecommons.org/licenses/by/4.0/

(c) (i) Open Access

\section{Abstract}

Several kinds of disinfectants were investigated in this paper for their ability to inhibit quorum sensing activities in water in distribution system. Among these disinfectants, free chlorine is the strongest inhibitor for QS activities and all disinfectants have inhibiting effect on QS activities in water. The results offered a novel approach for preventing formation of biofilm in distribution system.

\section{Keywords}

\section{Disinfectant, Inhibit, Quorum Sensing, Water of Distribution System, Formation of Biofilm}

\author{
Subject Areas: Environmental Sciences
}

\section{Introduction}

Water is an important part of life and the development of human beings. Microbial safety of drinking water has always been a focus in the field of drinking water research. In recent studies of distribution systems, it was found that biofilm microorganisms predominated over corresponding plank tonic cells. A possible reason was the ability of biofilm microorganisms to metabolize recalcitrant organic compounds and their greater resistance to chlorine and other biocides [1]. Disinfection with chlorine dioxide and chlorite, for example, can reduce the concentration of planktonic bacteria, but has little effect on the concentration of biofilm bacteria. Lapses in chlorination can lead to regrowth of biofilm communities and increased resistance of biofilm bacteria to chlorine. Many "emerging pathogens" in drinking water systems have increased threats to the health of human beings. A large number of these pathogens can form biofilms. Such findings indicated the importance of biofilms to the microbial safety of drinking water. 
Many studies suggest that bacterial quorum sensing (QS) plays an important role in the formation of biofilms [2] [3]. To understand the formation of biofilms, it is important to study bacterial quorum sensing of microorganisms in the distribution system. Through controlling quorum sensing, biofilm bacteria can be turned into plank tonic cells that are easily killed by dissociative chlorine. Thus, it is possible to inhibit the formation of biofilms by controlling quorum sensing. The microbiological safety of drinking water could be enhanced using disinfectants to control cell-communications among microorganisms in distribution network systems.

In order to biocontrol communications among bacterial cells in the distribution system, some inhibitor was selected to decrease QS activities in water. Several kinds of oxidants and disinfectants were investigated in this paper for their ability to inhibit QS activities in water. Hydrogen peroxide, potassium permanganate, ozone, chloramines hypochlorite, and chlorine dioxide were chosen because they are all commonly used in drinking water treatment. The objective of this work was to find an ideal approach to inhibit the formation of biofilms in the distribution systems.

\section{Materials and Methods}

\subsection{Materials}

\subsubsection{Reporter Strain}

Reporter strain KYC55 was obtained from Professor Jun Zhu, Nanjing Agricultural University. P. R. C [4].

\subsubsection{Reagents}

N-buty-DL-homoserine lactone (C4-HSL), N-OXO-hexanoyl-DL-homoserine lactone, (C6-OXO-HSL), N-OXOdodecanoyl-DL-homoserine lactone (C8-OXO-HSL), and N-dodeca-noyl-DL-homoserinelactone (C12-HSL) were bought from Sigma.

\subsubsection{AT Medium}

The reporter strain KYC55 was cultured in AT medium containing $\mathrm{KH}_{2} \mathrm{PO}_{4} 10.7$ g; $\mathrm{MgSO}_{4} \cdot 7 \mathrm{H}_{2} \mathrm{O} 148$ mg; $\mathrm{CaCl}_{2} \cdot 2 \mathrm{H}_{2} \mathrm{O} 8.8 \mathrm{mg} ; \mathrm{FeSO}_{4} \cdot 7 \mathrm{H}_{2} \mathrm{O} 7.5 \mathrm{mg} ; \mathrm{MnSO}_{4} \mathrm{H}_{2} \mathrm{O} 1.2 \mathrm{mg} ;\left(\mathrm{NH}_{4}\right)_{2} \mathrm{SO}_{4} 2$ g; glucose 5 g; $\mathrm{NaOH} 1.76 \mathrm{~g}$ and distilled water $1000 \mathrm{ml}$.

\subsection{Methods}

\subsubsection{Empirical Method}

Studying the effects of disinfectants on activities of bacterial quorum sensing in water: AHL powder was diluted to $1 \mathrm{mmol} / \mathrm{L}$ with sterile distilled water and was stored at $-20^{\circ} \mathrm{C}$. The AHL solution was diluted to $1 \mu \mathrm{mol} / \mathrm{L}$ before used. The disinfectants, which are often used in drinking water treatment were diluted and added to a 2-ml cuvette with AHL liquid. Then timed. The reaction liquid was called liquid 1 when the reaction time was arrived. The QS activities of liquid 1 was determined immediately after the reaction was complete [5].

\subsubsection{Determination Method}

QS activities were estimated using $\beta$-galactosidase activity method as described previously (2). Frozen KYC55 was melted in a vial and then $10 \mu \mathrm{l}$ was used to inoculate $10 \mathrm{ml}$ of AT medium in a cuvette without antibiotics, the $100 \mu \mathrm{l}$ of AHL C6or liquid 1 was also added. Then The KYC55 cells were incubated for 16 hour at $28^{\circ} \mathrm{C}$, until the OD 600 reached 0.2 to 1 . The sample at this point was referred to liquid 2. OD600 readings were taken for the total cell suspensions. $0.2 \mathrm{ml}$ of liquid 2 in AT medium were combined with $0.8 \mathrm{ml} \mathrm{Z} \mathrm{buffer,} 10 \mu \mathrm{l}$ of $0.1 \%$ SDS solution, and $15 \mu \mathrm{l}$ of chloroform in $5 \mathrm{ml}$ test tubes. Tubes were shaked vigorously for at least $10 \mathrm{sec}$ and then $0.4 \mathrm{ml}$ of $4 \mathrm{mg} / \mathrm{ml}$ ONPG was added. This point was recorded as time zero (T0). When the solution turned yellow, $0.6 \mathrm{ml}$ of $1 \mathrm{M} \mathrm{Na}_{2} \mathrm{CO}_{3}$ was added to stop the reaction, and the time was recorded in minutes (Ts). An OD420 reading was taken for the reaction liquid was measured OD420. Results were calculated results in Miller units as follows:

$$
\text { miller unit }=\frac{1000 * O D 420}{O D 600 * T * 0.2}
$$

In this paper, $\beta$-galactosidase activity was indicated QS activities. 


\section{Results and Discussions}

\subsection{Denotation QS Activities}

Reporter strain KYC55 reacting different ranges of AHL molecules were indicated in Figure 1; Different types of AHL showed different $\beta$-galactosidase activity. $10 \mathrm{nmol} / \mathrm{L}$ C6 AHL showed the highest activity and $10 \mathrm{nmol} / \mathrm{L}$ C4, C12 demongstrated much lower.

Under normal conditions, AHL molecules are mixture in water in distribution systems. However, $\beta$-galactosidase activity on certain ratio AHL mixture was not stable. Therefore, $10 \mathrm{nmol} / \mathrm{L}$ C6 AHL was selected to measure QS activities in water in distribution systems. As indicated in Figure 1, QS activities of 10 nmol C6 was approximately 1000 miller units. This result was reliably obtained in several parallel experiments. In the experiments below, the effect of different disinfectants on $10 \mathrm{nmol} / \mathrm{L}$ C6 AHL liquid will be studied to denote inhibiting QS activities (Figure 2).

\subsection{Chlorination}

To supply safe, microbe-free drinking water, a chlorination process is usually conducted. Chlorination is the predominant disinfection method applied in water treatment due to its low cost, ease of application, and ability to inactivate a wide variety of pathogenic microorganisms.

However, an important drawback is the formation of harmful chlorination disinfection by-products (DBPs). Some of these DBPs have been linked to cancer and reproductive defects [6] [7].

The effect of active chlorine on QS activities in water is shown in Figure 3. Free chlorine from Javel water can evidently inhibit QS activities in water. Even at low concentrations $0.05 \mathrm{mg} / \mathrm{L}$ free chlorine, it can significantly inhibit QS activities in water at $12 \mathrm{~h}$. AHL molecules can be hydrolyzed by alkali in Javel water. MX, a kind of chlorination disinfection by-products and an AHL analog, are likely to be the reasons for decreasing QS activities.

\subsection{Chloramination}

There has been a strong trend toward replacing free chlorine with chloramine in drinking water treatment in order to meet stricter limits on chlorine disinfectant byproducts. Chloramine is generally thought to produce a

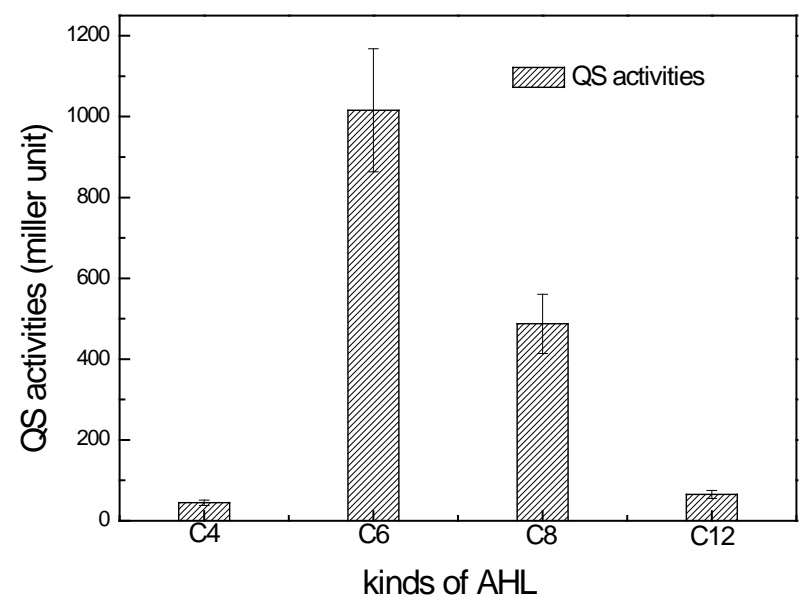

Figure 1. Effect of kinds of AHL on QS activities in water.<smiles>[R]C(=O)CC(=O)OC1CCOC1=O</smiles>

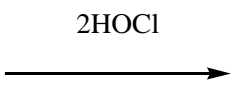<smiles>[R]C(=O)C(Cl)(Cl)C(=O)O[R]C1(Cl)CCOC1=O</smiles> 


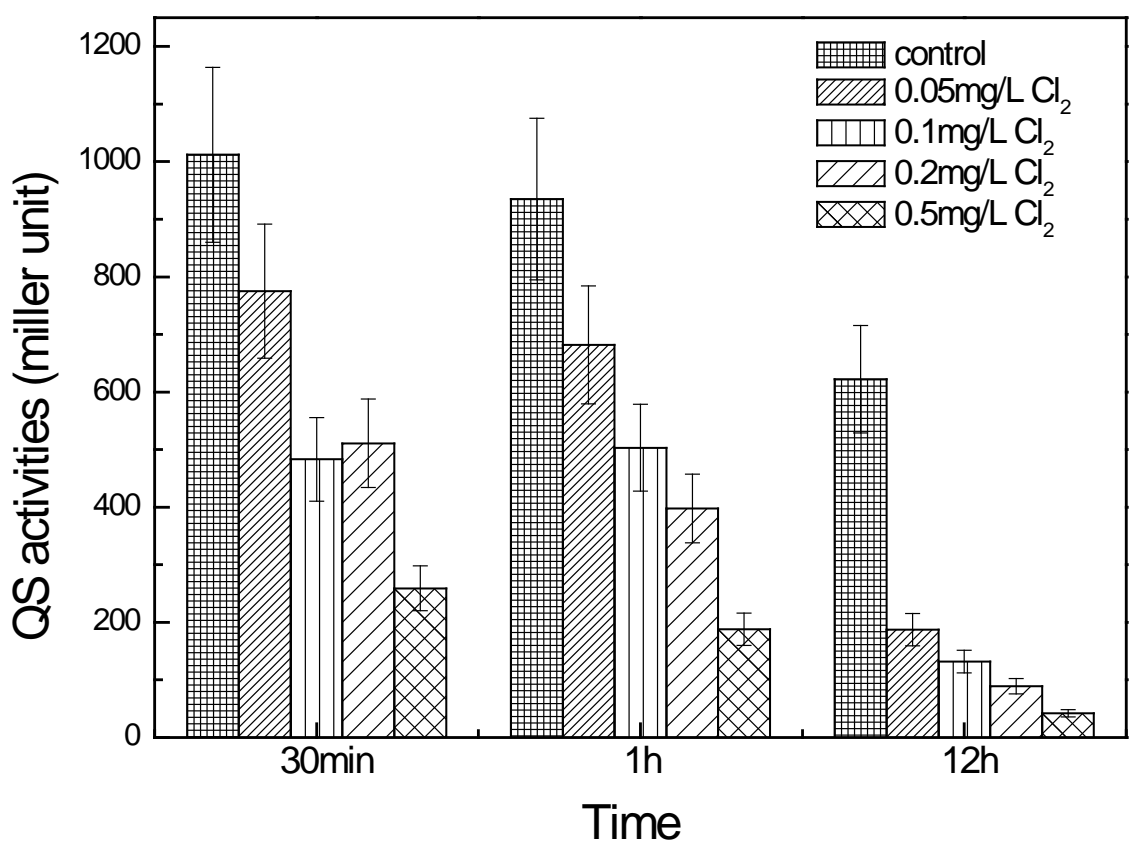

Figure 3. Effect of active chorine on QS activities in water.

more stable residual than free chlorine and thus provide lasting protection against bacteria regrowth in distribution systems. In addition, chloramine is believed to penetrate more deeply than chlorine within the biofilmthus providing for greater inactivation [8].

Chloramine was generated using Javel water $(1000 \mathrm{mg} / \mathrm{L})$ and ammonium chloride solution $\left(\mathrm{NH}^{+}{ }_{4}-\mathrm{N} 1000\right.$ $\mathrm{mg} / \mathrm{L})$ at $\mathrm{Cl}_{2}: \mathrm{N}$ ratio of $4: 1(\mathrm{w} / \mathrm{w})$, with a final $\mathrm{pH}=9.0$ and low temperature.

The effect of chloramines on QS activities in water is shown in Figure 4. Similar to Chlorine, QS activities in water decreased greatly with chloramination at higher dosages and longer times. QS activities was much lower, when concentration of chloramines reached over $5 \mathrm{mg} / \mathrm{L}$ and 12 hour. There are no activities over $20 \mathrm{mg} / \mathrm{L}$ in 12 hour. This indicated that chloramines need a long time to react with AHL molecules.

\subsection{Chlorine Dioxide}

Chlorine dioxide is a powerful hypochlorite and an alternative disinfectant agent to chlorine for disinfection and oxidation during the treatment of drinking water. Chlorine dioxide readily dissolves in water to form a solution that is a biocide to a wide range of microorganisms. It is also known that chlorine dioxide undergoes disproportionations in water, producing chlorite and chlorate. The major advantage of chlorine dioxide is that the disinfection process does not generate large quantities of halogenated by-products that are common with chlorination. Another advantage is that chlorine dioxide significantly reduces odor and color [9].

As indicated in Figure 5, $5 \mathrm{mg} / \mathrm{L}$ chlorine dioxide has strong inhibitory effects on QS activities in water. 2 $\mathrm{mg} / \mathrm{L}$ of chlorine dioxide after 12 hours decreased QS activities greatly. Low concentrations of $\mathrm{ClO}_{2}$ play little part in communication of water in distribution system. The range of chlorine dioxide concentrations that are used in water treatment is $0.02-0.8 \mathrm{mg} / \mathrm{L}$ according to national regulation. Therefore, chlorine dioxide is not an ideal disinfectant to inhibit QS activities in water.

\subsection{Potassium Permanganate $\left(\mathrm{KMnO}_{4}\right)$}

$\mathrm{KMnO}_{4}$ is a strong and active oxidant, which reacts with a wide variety of organic and inorganic substances. In drinking water treatment technology, it is primarily used for taste and odor control. Its secondary role is to control the formation of trihalomethanes (THMs) and other DBPs oxidizing of their precursors. Previous studies have demonstrated that potassium permanganate may be a feasible oxidants for the removal of MCs present in drinking water resources, although theoxidation might lead to toxic oxidation products [10]. 


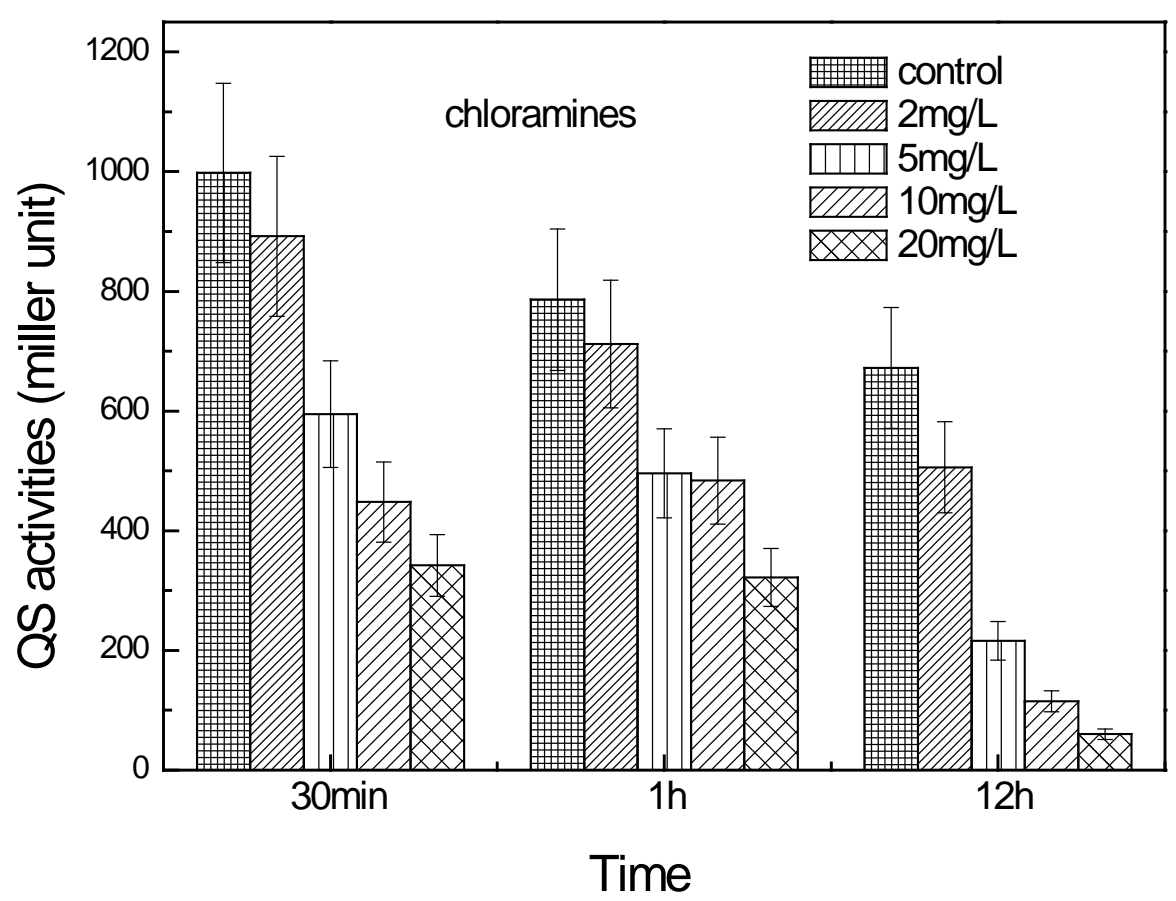

Figure 4. Effect of chloramines on QS activities in water.

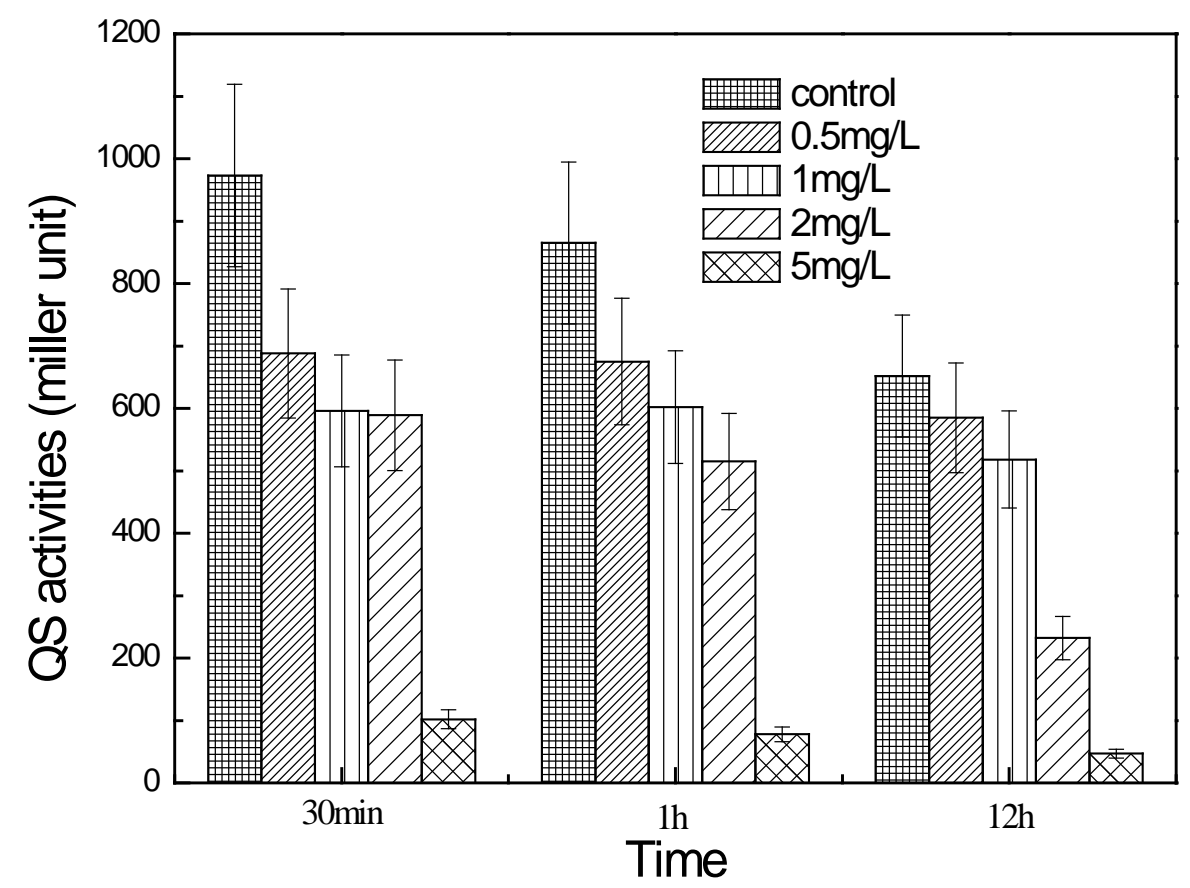

Figure 5. Effect of chlorine dioxide on QS activities in water.

The variation of QS activities at different $\mathrm{KMnO}_{4}$ concentration is indicated in Figure 6; at low concentration, $\mathrm{KMnO}_{4}$ significantly decreased QS activities in water. However, it was not evident that QS activities further decreased with increases of $\mathrm{KMnO}_{4}$ contentration. Long treatment times with $\mathrm{KMnO}_{4}$ did not dramatically decrease QS activities. Therefore, short treatment times and at a low dosage of $\mathrm{KMnO}_{4}$ was satisfactory for inhibiting QS activities in water. 


\subsection{Hydrogen Peroxide}

Hydrogen peroxide, as well as other non-chlorine disinfectants, is usually coupled with ozone or chloramines in drinking water pretreatment. Its advantages over other oxidants are that it is nontoxic, harmless, and generates environmentally acceptable by products [11].

The effect of hydrogen peroxide on QS activities in water is showed in Figure 7. The QS activities decreased with increasing hydrogen peroxide concentrations. High concentrations of hydrogen peroxide treatment (over 5 $\mathrm{mmol} / \mathrm{L}$ ) notably decreased $\beta$-galactosidase activity in water. Therefore, decreasing QS activities requires long treatment times and high doses of hydrogen peroxide.

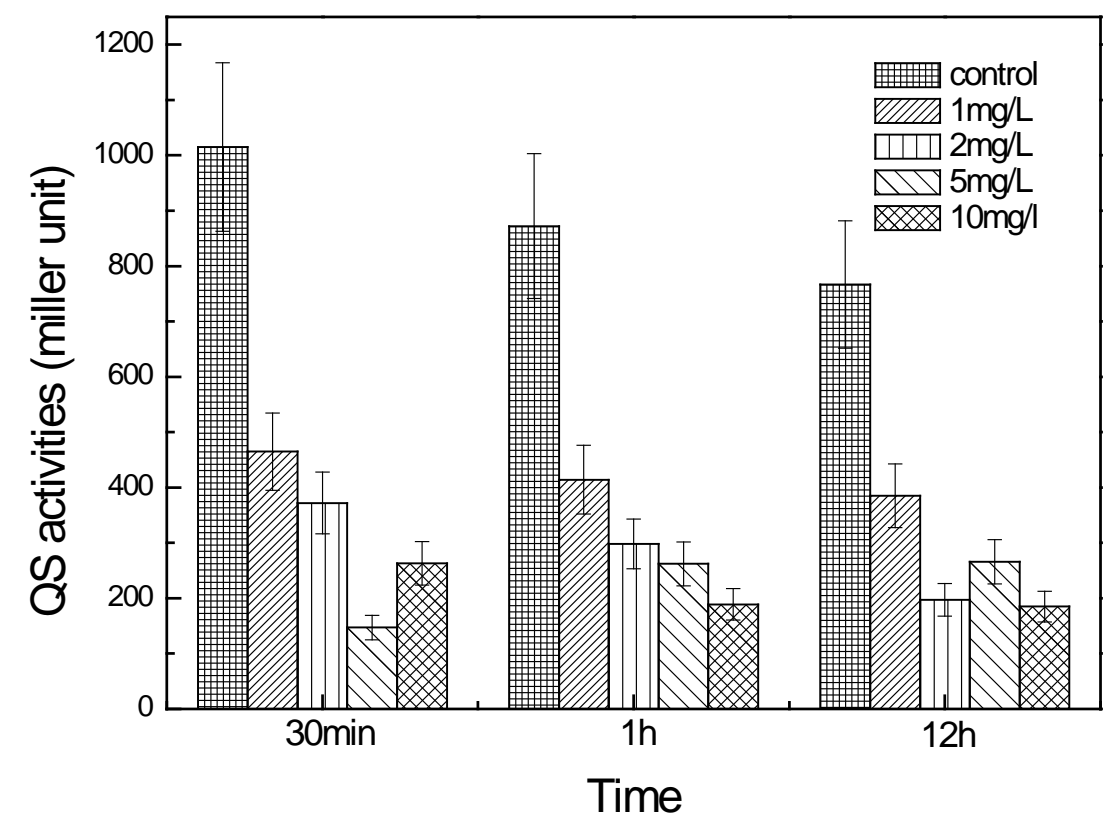

Figure 6. Effect of $\mathrm{KMnO}_{4}$ on QS activities in water.

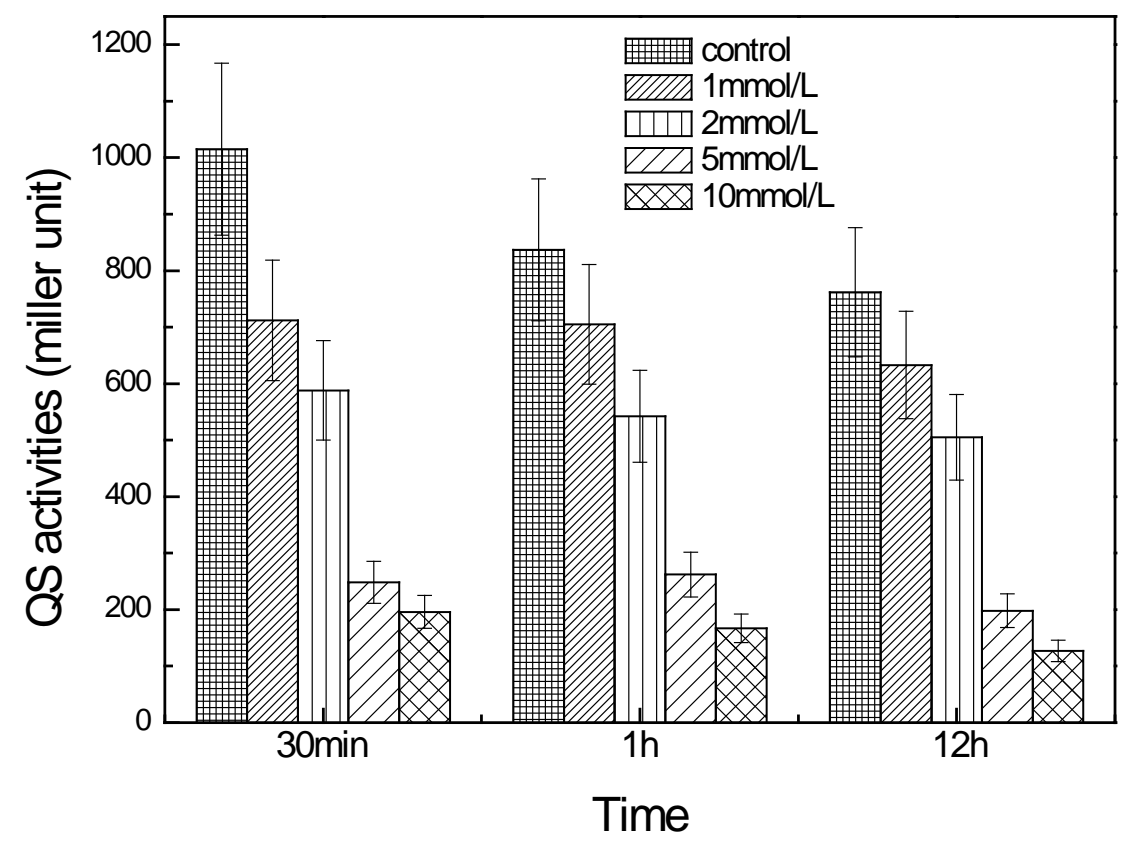

Figure 7. Effect of hydrogen peroxide on QS activities in water. 


\section{Conclusions}

(1) Reporter strain KYC55 is most sensitive to C6 AHL; therefore, C6 AHL was selected as an indicator of QS in water.

(2) All disinfectants tested in this study were able to inhibit QS activities in water to a certain extent. Javel water was the strongest oxidant and the lowest oxidant was chlorine dioxide.

\section{References}

[1] Szewzyk, U. and Szewzyk, R. (2000) Microbiological Safety of Drinking Water. Annual Review of Microbiology, 54, 81-127. http://dx.doi.org/10.1146/annurev.micro.54.1.81

[2] Joelsson, A.C. and Zhu, J. (2006) LacZ-Based Detection of Acyl-Homoserine Lactone Quorum-Sensing Signals. Current Protocols in Microbiology, 1C.2.1-1C.2.9.

[3] Waters, C.M. and Bassler, B.L. (2005) Quorum Sensing: Cell-to-Cell Communication in Bacteria. Annual Review of Cell and Developmental Biology, 21, 319-346. http://dx.doi.org/10.1146/annurev.cellbio.21.012704.131001

[4] Zhu, J., Chai, Y.R., Zhong, Z.T., Li, S.P. and Winans, S.C. (2003) Agrobacterium Bioassay Strain for Ultrasensitive Detection of $\mathrm{N}$-Acylhomoserine Lactone-Type Quorum-Sensing Molecules: Detection of Autoinducers in Mesorhizobium huakuii. Applied and Environmental Microbiology, 69, 6949-6953.

[5] Kumari, A., Pasini, P. and Deo, S.K. (2006) Biosensing Systems for the Detection of Bacterial Quorum Signaling Molecules. Analytical Chemistry, 78, 7603-7609. http://dx.doi.org/10.1021/ac061421n

[6] Butterfield, P.W. and Camper, A.K. (2002) Chlorination of Model Drinking Water Biofilm: Implications for Growth and Organic Carbon Removal. Water Research, 36, 4391-4405. http://dx.doi.org/10.1016/S0043-1354(02)00148-3

[7] Leea, W. and Westerhoffb, P. (2009) Formation of Organic Chloramines during Water Disinfection-Chlorination versus Chloramination. Water Research, 43, 2233-2239.

[8] Huaa, G.H. and Reckhowa, D.A. (2007) Comparison of Disinfection Byproduct Formation from Chlorine and Alternative Disinfectants. Water Research, 41, 1667-1678. http://dx.doi.org/10.1016/j.watres.2007.01.032

[9] Navalon, S., Alvaro, M. and Garcia, H. (2009) Chlorine Dioxide Reaction with Selected Amino Acids in Water. Journal of Hazardous Materials, 164, 1089-1097. http://dx.doi.org/10.1016/j.jhazmat.2008.09.010

[10] Lee, C., Yoon, J. and Von Gunten, U. (2007) Oxidative Degradation of N-Nitrosodimethylamine by Conventional Ozonation and the Advanced Oxidation Process Ozone/Hydrogen Peroxide. Water Research, 41, 581-590. http://dx.doi.org/10.1016/j.watres.2006.10.033

[11] Kepa, U. and Stanczyk-Mazanek, E. (2008) Ozone + Hydrogen Peroxide System for the Removal of Cyanide from Water. Desalination, 223, 187-193. http://dx.doi.org/10.1016/j.desal.2007.01.215 